\title{
Perbandingan Metode Indeks Vegetasi NDVI, SAVI dan EVI Terkoreksi Atmoafer iCOR
}

\author{
Hardianto $^{1)}$, Laode M. Golok Jaya ${ }^{2)}$, Nurgiantoro ${ }^{3)}$, Noor Husna Khairisa ${ }^{4)}$ \\ 1) Geografi Fakultas Ilmu dan Teknologi Kebumian Universitas Halu Oleo \\ 2) Jurusan Geografi Fakultas Ilmu dan Teknologi Kebumian Universitas Halu Oleo \\ 3) Jurusan Geografi Fakultas Ilmu dan Teknologi Kebumian Universitas Halu Oleo \\ 4) Jurusan Geografi Fakultas Ilmu dan Teknologi Kebumian Universitas Halu Oleo \\ E-mail : ${ }^{1)}$ hardiantosgeo@ gmail.com, ${ }^{2)}$ laodemgj@gmail.com,${ }^{2)}$ nurgiantoro@uho.ac.id
}

\begin{abstract}
Abstrak: Koreksi atmosfer merupakan turunan metode dari koreksi radiometrik dari kategori koreksi yang mempertimbangkan faktor-faktor luar yang berpengaruh terhadap kesalahan informasi yang ada pada citra. Dalam penelitian ini, koreksi atmosfer dilakukan pada Citra Landsat 8 OLI dikarenakan memiliki akses data yang relatif mudah. Penelitian ini bertujuan untuk menerapkan hasil koreksi BoA iCOR pada indeks vegetasi metode NDVI, SAVI dan EVI. Metode analisis data yang digunakan dalam penelitian ini, metode transformasi indeks vegetasi NDVI, SAVI dan EVI untuk mengidentifikasi tingkat kerapatan vegetasi. Hasil penelitian ini antara lain rentang nilai kerapatan vegetasi terkoreksi atmosfer iCOR metode NDVI -0,63 sampai 1,42; SAVI -0,14 sampai 0,37; dan EVI -0,15 sampai 0,35 dari citra hasil koreksi iCOR. Hasil koreksi iCOR baik diterapkan pada metode transformasi NDVI sedangkan metode transformasi SAVI dan EVI kurang baik diterapkan karena tidak mendekati rentang indeks vegetasi secara global.
\end{abstract}

\section{Kata Kunci: NDVI, SAVI, EVI}

\begin{abstract}
Atmospheric correction is a method derived from the radiometric correction of the correction category that considers the external factors affecting the misinformation of the imagery. In this research, the correction of atmosphere is carried out on Citra Landsat 8 OLI because it has relatively easy data access. This research aims to Applying BoA iCOR correction results on the vegetation index of NDVI, SAVI and EVI methods. The data analysis method used in this study for the purpose of The Vegetation index transformation methods of NDVI, SAVI and EVI to identify vegetation density levels. The results of this research include Range of atmospheric corrected vegetation density value of iCOR method NDVI-0.63 to 1.42 ; SAVI-0.14 to 0.37 ; and EVI-0.15 to 0.35 from the image of iCOR correction results. ICOR correction result is good applied to NDVI transformation method while SAVI and EVI transformation methods are less well implemented as not approaching vegetation index range globally
\end{abstract}

Keywords: NDVI, SAVI, EVI 


\section{PENDAHULUAN}

Penginderaan jauh optik merupakan penginderaaan jauh yang memanfaatkan panjang gelombang sepektral yang digunakan oleh sebuah satelit. Penginderaan jauh optik menggunakan panjang gelombang tampak, inframerah dekat, dan inframerah gelombang pendek untuk membentuk sebuah citra atau gambar dari permukaan bumi dengan mendeteksi radiasi yang dipantulkan target pada permukaan bumi. Material yang berbeda akan menyerap dan memancarkan energi secara berbeda pula dalam setiap panjang gelombang. Dengan demikian target dapat dibedakan pada citra penginderaan jauh. Penginderaan jauh sistem optik dapat dibedakan berdasarkan jumlah saluran spektral yang digunakan dalam prosesan citra.

Landsat 8 memiliki 11 saluran, saluran ke 5 adalah saluran inframerah yang memiliki kegunaan dalam identifikasi obyek berupa vegetasi. Berdasarkan 123 hal tersebut, sampai saat ini telah banyak dilakukan penelitian penginderaan jauh dalam bidang vegetasi termasuk diantaranya adalah mengenai hutan. Keunggulan penginderaan jauh dalam hal multiwaktu serta pantulan vegetasi yang khas pada saluran inframerah memungkinkan untuk dilakukannya penelitian terhadap perubahan kerapatan kanopi hutan sebagaimana yang terjadi pada kawasan hutan lindung Gunung Kelud (Himayah, 2017).

Upaya untuk menganalisis tingkat kerepatan vegetasi di suatu daerah dengan menggunakan pendekatan spektral, diperlukan citra satelit dengan gangguangangguan atmosfer yang sedikit. Dimana ini memerlukan koreksi pada citra tersebut. Adapun koreksi yang digunaakn untuk menghilangkan efek atmosfer tersebut yaitu menggunakan koreksi atmosfer.
Koreksi atmosfer merupakan koreksi yang dilakukan untuk menghapus efek atmosfer dari sinyal yang direkam oleh sensor. Koreksi atmosfer dilakukan dengan cara mengkonversi nilai radian ToA (Top of Atmospheric) ke nilai reflektan BoA (Bottom of Atmospheric) (Arafah, 2015).

Salah satu metode koreksi atmosfer yang sering di gunakan yaitu koreksi ToA reflektan, namun koreksi ini hanya menghilangkan efek-efek atmosfer yang ada dibagian atas atmosfer namun tidak bagian bawanya. Pada penelitian ini peneliti menggunakan metode koreksi BoA (Bottom of Atmospheric).

Metode koreksi reflektan BoA terdiri dari beberapa metode diantaranya metode FLAAS, 6S (Second Simulation of the Sensor Signal in the Solar Spectrum), DOS (Dark Object Substraction), iCOR (image correction for atmospheric effects), dan masih banyak lagi. Pada metode-metode koreksi atmosfer BoA di atas, memiliki kelebihan dan kekuranganya masingmasing tetapi memiliki fungsi yang sama yaitu untuk menghilangkan efek-efek gangguan atmosfer.

Berdasarkan uraian diatas peneliti memilih menggunakan metode koreksi atmosfer iCOR. Dikarenakan metode koreksi atmosfer iCOR memiliki kelebihan dimana, koreksi atmosfer iCOR memiliki kelebihan mampu melakukan koreksi kolom air serta pengerjaanya mudah dan cepat. Itulah yang membuat peneliti tertarik melakukan penelitian dengan menggunakan metode koreksi atmosfer iCOR.

\section{METODE PENELITIAN}

\subsection{Lokasi Penelitian}

Lokasi penelitian pada Perbandingan indeks vegetasi NDVI, SAVI dan EVI terkoreksi atmoafer iCOR pada aplikasi SNAP. Daerah yang menjadi wilayah kajian merupakan daerah Kota Kendari. Lokasi penelitian dapat dilihat pada Gambar 1. 


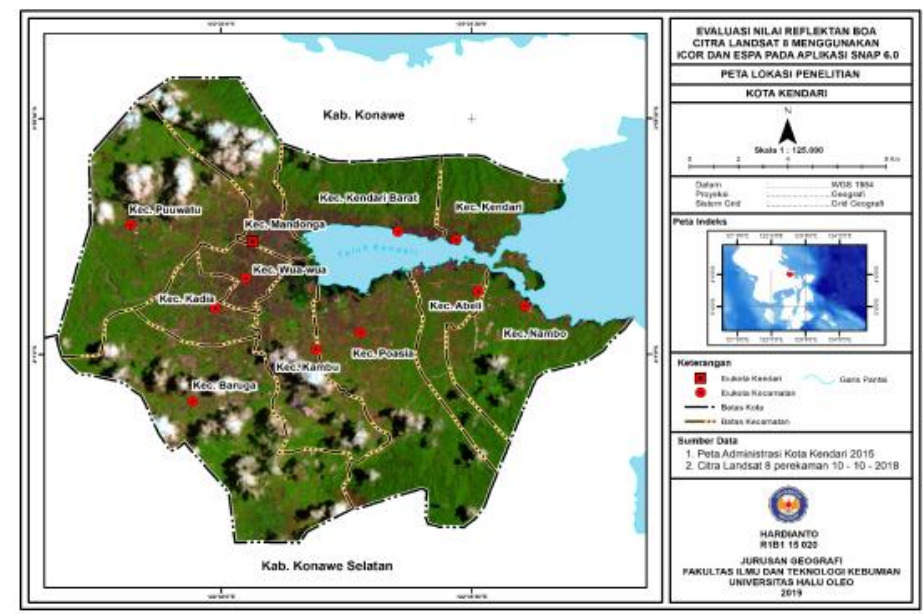

Gambar 1. Peta Lokasi Penelitian

\subsection{Tahapan Pengolahan Data Koreksi Atmosfer}

Koreksi atmosfer merupakan suatu koreksi pada citra yang dilakukan dengan mengubah nilai digital number menjadi radian BoA. Proses koreksi BoA ini dilakukan dengan mempertimbangkan koreksi atmosfer dengan mempertimbangkan parameter - parameter dalam koreksi atmosfer dan dilakukan dengan berbagai macam metode sesuai dengan bidang yang dikaji (Jaelani, 2016 dalam Kristianingsih dkk, 2016).

Koreksi atmosfer yang digunakan dalam penelitian ini yaitu koreksi atmosfer iCOR. Koreksi atmosfer iCOR merupakan koreksi umum atmosfer dengan menggunakan algoritma sensor yang dapat memproses gambar dan mengandung tanah dan piksel air pesisir, darat atau transisi (Stefan, 2018).

Tujuan utamanya adalah memperbaiki produk dari efek atmosfer. Output dari iCOR ini adalah produk yang masih menghasilkan reflectance ToA (Top of Atmosphere), sehingga produknya masih harus dikonversi menjadi reflectance BoA. Oleh (Main-Knorn et al, 2017 dalam Nurgiantoro, 2018), konversi ToA ke BoA memberikan ketidak pastian pada reflektansi permukaan hingga 0.04 sehingga untuk menghindari ketidak pastian tersebut, produk iCOR pada masing-masing band harus dibagi $\pi$ untuk mendapatkan $\operatorname{Rrs}(\lambda)$ dalam satuan $\mathrm{Sr}^{-}$
${ }^{1}$ (Bobsaid \& Jaelani, 2017 dalam Nurgiantoro, 2018).

\section{Pemotongan Citra}

Pemotongan citra atau cropping merupakan proses pengolahan citra yang digunakan untuk memperkecil daerah pengamatan suatu penelitian. Pemotongan Citra dilakukan guna memperkecil Daerah studi kasus Wilayah Penelitian di Kota Kendari.

\section{Indeks Vegetasi}

Indeks vegetasi merupakan suatu bentuk transformasi spektral yang diterapkan terhadap citra multisaluran untuk menonjolkan aspek kerapatan vegetasi ataupun aspek lain yang berkaitan dengan kerapatan, misalnya biomassa, Leaf Area Index (LAI), konsentrasi klorofil dan sebagainya. Secara praktis, indeks vegetasi ini merupakan suatu transformasi matematis yang melibatkan beberapa saluran sekaligus, dan menghasilkan citra baru yang lebih representatif dalam menyajikan fenomena vegetasi.

Berkaitan dengan hal itu, dalam penelitian ini menggunakan algoritma NDVI, EVI, dan SAVI yang di terapkan pada Citra Landsat 8 terkoreksi iCOR. Adapun indeks vegetasi yang digunakan adalah sebagai berikut :

\section{a. Normalized Difference Vegetation Indeks (NDVI)}


Menentukan nilai kerapatan tajuk vegetasi menggunakan hasil dari perhitungan NDVI dengan formula sebagai berikut: (Ikkarnila, 2017)

NDVI $=\frac{\rho_{\text {NIR. }} \cdot \rho_{\text {Red }}}{\rho_{\text {NIR }+} \rho_{\text {Red }}}$

Dimana :

$\rho_{\mathrm{NIR}}=$ nilai band inframera dekat

$\rho_{\text {Red }}=$ nilai band merah

\section{b. Soil Adjusted Vegetation Indeks}

(SAVI)

rumus yang dimasukkan untuk algoritma SAVI, adalah (USGS, 2017)

SAVI $=\frac{\rho_{\mathrm{NIR}}{ }^{-} \rho_{\mathrm{Red}}}{\rho_{\mathrm{NIR}}+\rho_{\mathrm{Red}}+\mathrm{L}} *(1+\mathrm{L})$

Dimana :

$\rho_{N I R}=$ reflektance inframerah dekat

$\rho_{\text {Red }}=$ reflektance band merah

$\mathrm{L} \quad=$ koreksi kecerahan tanah yang didefinisikan sebagai 0,5

c. Enhanced Vegetation Indeks (EVI)

Rumus yang dimasukkan untuk algoritma EVI, adalah (Huete dkk., 2007 dalam Hernawati, 2017) :

EVI $=2,5 \frac{\rho_{\text {NIR }}-\rho_{\text {Red }}}{\rho_{\text {NIR }}+6^{*} \rho_{\text {Red }}-7,5^{*} \rho_{\text {Blue }}+1}$

Dimana :

$\rho_{\mathrm{NIR}}=$ reflektance inframerah dekat

$\rho_{\text {Red }}=$ reflektance band merah

$\rho_{\text {Blue }}=$ reflectance band biru

\section{Hasil DAN PEMBAHASAN Gambaran Umum Lokasi Penelitian}

Kota Kendari merupakan salah satu Kotayang terletak di Provinsi Sulawesi Tenggara serta merupakan Ibu Kota dari Provinsi Sulawesi Tenggara. Secara astronomis Kota Kendari terletak di bagian selatan garis khatulistiwa berada diantara $3^{0} 54$ ' 40" dan 405'05" LS dan membentang dari Barat ke Timur diantara $122^{\circ} 26$ ' $33^{\prime \prime}$ dan $122^{0} 39$ '14" BT. Dilihat berdasarkan ketinggian wilayah Kota Kendari di atas permukaan laut, Kecamatan Mandonga 56 --- April merupakan wilayah tertinggi berada pada ketinggian 45 meter di atas permukaan laut. Selanjutnya wilayah Kecamatan Puuwatu dan Baruga masing-masing berada pada ketinggian 31 dan 29 meter di atas permukaan laut. Wilayah penelitian terletak diKota Kendari. Wilayah yang menjadi lokasi penelitian dan luasan, dapat dilihat dalam tabel berikut.

Tabel 1. Luas Wilayah Penelitian

\begin{tabular}{cll}
\hline No & \multicolumn{1}{c}{ Nama Kecamatan } & $\begin{array}{c}\text { Luasan } \\
\text { (ha) }\end{array}$ \\
\hline $\mathbf{1}$ & Kecamatan Abeli & 1424.23 \\
\hline $\mathbf{2}$ & Kecamatan Baruga & 4923.44 \\
\hline $\mathbf{3}$ & Kecamatan Kadia & 648.3 \\
\hline $\mathbf{4}$ & Kecamatan Kambu & 2198.38 \\
\hline $\mathbf{5}$ & Kecamatan Kendari & 1437.44 \\
\hline $\mathbf{6}$ & Kecamatan Kendari Barat & 2039.06 \\
\hline $\mathbf{7}$ & Kecamatan Mandonga & 2166.67 \\
\hline $\mathbf{8}$ & Kecamatan Nambo & 2523.41 \\
\hline $\mathbf{9}$ & Kecamatan Poasia & 4222.39 \\
\hline $\mathbf{1 0}$ & Kecamatan Puuwatu & 4336.78 \\
\hline $\mathbf{1 1}$ & Kecamatan Wua-wua & 1058.89 \\
\hline Sumber & : Hasil Analisis Pengolahan Data \\
& Tahun 2019
\end{tabular}

\section{Koreksi Atmosfer iCOR}

Berdasarkan hasil koreksi Atmosfer iCOR pada citra Landsat 8 OLI terdapat perbedaan nilai pantulan untuk masingmasing hasil koreksi citra. Perbedaan nilai pantulan dapat dilihat pada grafik nilai pantulan yang disajikan pada gambar 2 . Berikut adalah tampilan grafik citra Landsat 8 Sebelum dan setelah dilakukan koreksi Atmosfer.

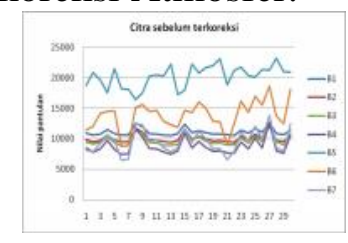

(a)

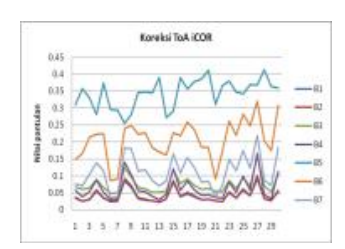

(b)

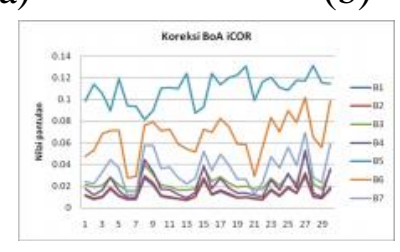

(c)

Gambar 2. Grafik Nilai Pantulan Citra (A)

Citra Sebelum di Koreksi (B) Citra terkoreksi Reflektance ToA (B) Citra Terkoreksi Reflektan BoA 
Pada gambar 2 menunjukan perbedaan nilai pantulan pada citra sebelum dan sesudah di koreksi, dimana nilai pantulan yang di hasilkan semakin menurun setelan di lakukan koreksi atmosfer.

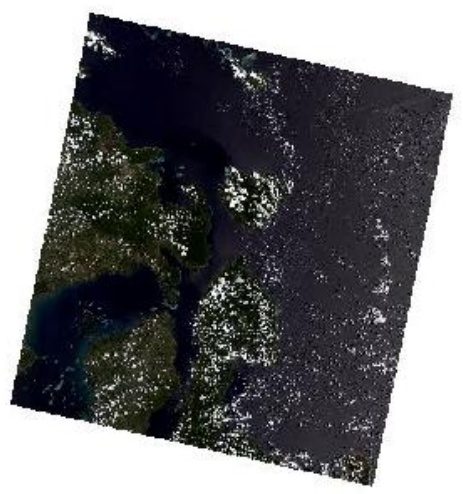

(a)

\section{Pemotongan Citra}

Pemotongan citra dilakukan untuk memperkecil wilayah penelitian. Wilayah pada menelitian ini terletak di Kota Kendari. Hasil cropping citra dapat dilihat pada

gambar 3.

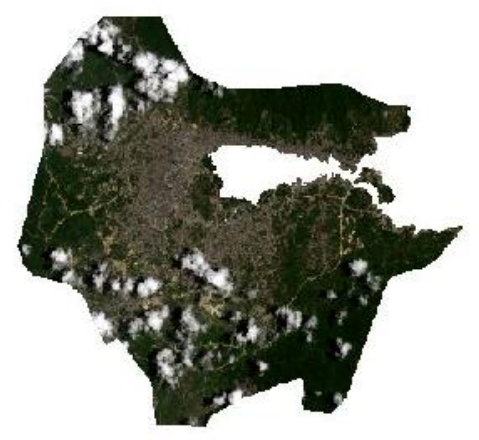

(b)

Gambar 3. Cropping Citra (A) Citra Belum Terpotong (B) Lokasi Penelitian Kota Kendari

\section{Indeks Vegetasi}

Indeks vegetasi adalah salah satu parameter yang digunakan untuk menganalisa keadaan vegetasi dari suatu wilayah. Indeks tersebut mempunyai berbagai macam variasi algoritma. Sejumlah penurunan dan alternatif NDVI telah diusulkan oleh sejumlah peneliti untuk menyempurnakan berbagai kekurangan parameter ini, Soil Adjusted Vegetation Index (SAVI), dan Enhanced Vegetation Index (EVI). Sesuai namanya, masing-masing indeks tersebut dihitung dengan memasukkan faktor koreksi terhadap satu atau beberapa faktor yang menjadi kekurangan NDVI (Purwanto, 2015).

Tabel 2. Tingkat kerapatan vegetasi

\begin{tabular}{ccc}
\hline Kelas & $\begin{array}{c}\text { Kerapatan } \\
\text { Vegetasi }\end{array}$ & Keterangan \\
\hline 1 & $-1 \mathrm{~s} / \mathrm{d}-0.03$ & $\begin{array}{l}\text { Lahan tidak } \\
\text { bervegetasi }\end{array}$ \\
\hline
\end{tabular}

\begin{tabular}{ccl}
\hline Kelas & $\begin{array}{c}\text { Kerapatan } \\
\text { Vegetasi }\end{array}$ & Keterangan \\
\hline 2 & $-0.03 \mathrm{~s} / \mathrm{d} 0.15$ & $\begin{array}{l}\text { Kehijauan } \\
\text { sangat rendah }\end{array}$ \\
\hline 3 & $0.15 \mathrm{~s} / \mathrm{d} 0.25$ & $\begin{array}{l}\text { Kehijauan } \\
\text { rendah }\end{array}$ \\
\hline 4 & $0.25 \mathrm{~s} / \mathrm{d} 0.35$ & $\begin{array}{l}\text { Kehijauan } \\
\text { sedang }\end{array}$ \\
\hline 5 & $0.35 \mathrm{~s} / \mathrm{d} 1.00$ & $\begin{array}{l}\text { Kehijauan } \\
\text { tinggi }\end{array}$ \\
\hline
\end{tabular}

Sumber : Peraturan mentri kehutanan Republik Indonesia

\section{Normalized Difference Vegetation Indeks}

Prinsip dari algoritma ini adalah radiasi dari visible red diserap oleh chlorophyll hijau daun sehingga akan direflektansikan rendah, sedangkan radiasi dari sinar near infrared akan kuat direflektansikan oleh struktur daun spongy mesophyll. Indeks ini mempunyai kisaran nilai dari $-1,0$ sampai 1,0 (Arhatin, 2007 dalam kawamuna 2017). 


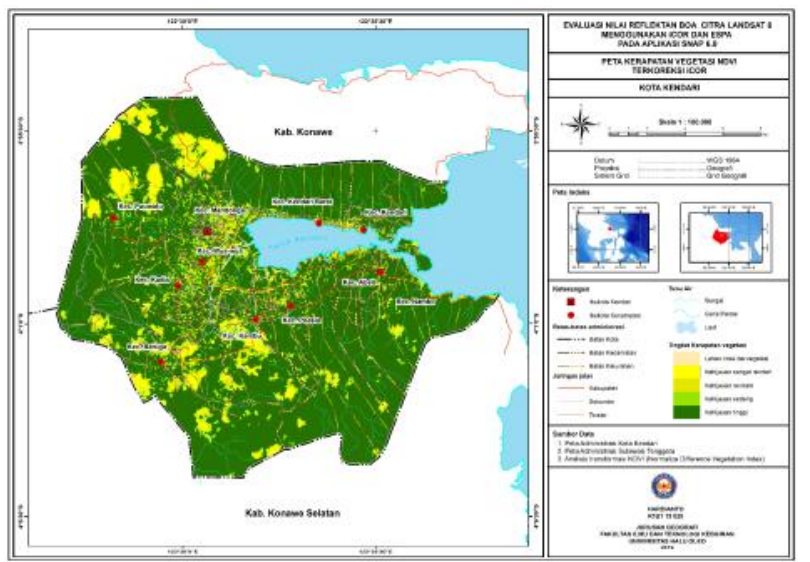

Gambar 4. Transformasi NDVI terkoreksi atmosfer iCOR

Pada gambar 4 menunjukan tingkat kerapatan vegetasi transformasi NDVI dengan lima rentang kelas, diataranya lahan tidak bervegetasi berwarna krim, kehijauan sangat rendah berwarna kuning, kehijauan rendah berwarna kuning muda, kehijauan sedang berwarna hijau dan kehijauan tinggi berwarna hijau.

\section{Soil Adjusted Vegetation Indeks}

Soil Adjusted Vegetation Index
(SAVI)
merupakan algoritma pengembangan dari NDVI dengan menekan pengaruh latar belakang tanah pada tingkat kecerahan kanopi. SAVI menggunakan persamaan isoline vegetasi (vegetasi dengan kerapatan sama dan latar belakang tanah berbeda) yang diturunkan melalui aproksimasi reflektansi kanopi dengan sebuah model interaksi foton orde pertama antara kanopi dan lapisan tanah. Penurunan spektral campuran merah, arena tanahyang lebih gelap, menyebabkan peningkatan signifikan pada NDVI. (Huete dalam,

Nurilmi 2017).

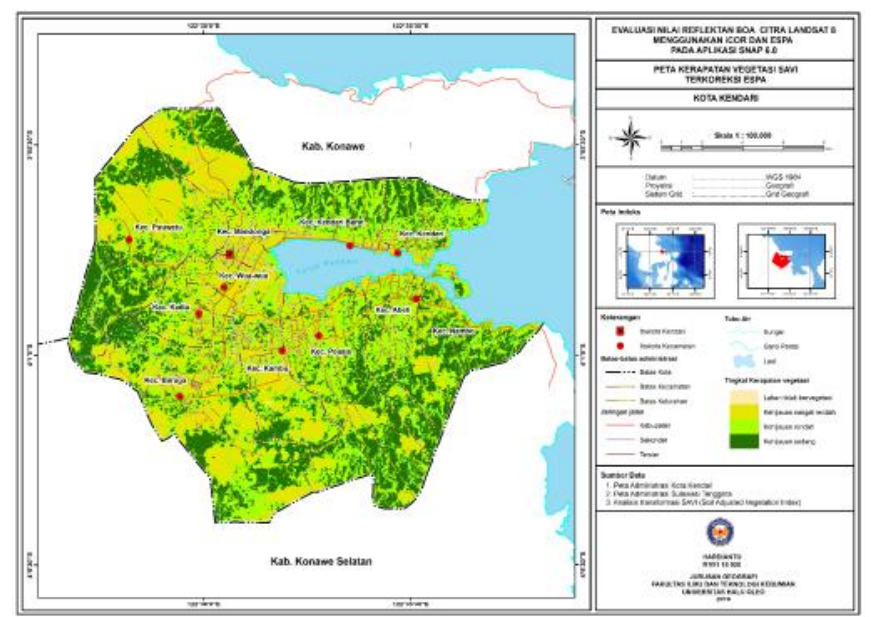

Gambar 5. Transformasi SAVI terkoreksi atmosfer iCOR

Pada gambar 5 menunjukan tingkat kerapatan vegetasi transformasi SAVI dengan empat rentang kelas, diataranya lahan tidak bervegetasi berwarna krim, kehijauan rendah berwarna kuning muda, kehijauan sedang berwarna hijau dan kehijauan tinggi berwarna hijau.

\section{Enhanched Vegetation Index}

Andana (2015) mengungkapkan Enhanched Vegetation Index (EVI) merupakan indeks vegetasi yang dikembangkan untuk meminimalkan pengaruh latar belakang kanopi dan variasi atmosfir yang lebih baik dari NDVI. EVI 
dihitung dengan menggunakan reflektan infra merah dekat (NIR). dari band biru (blue), merah (red), dan

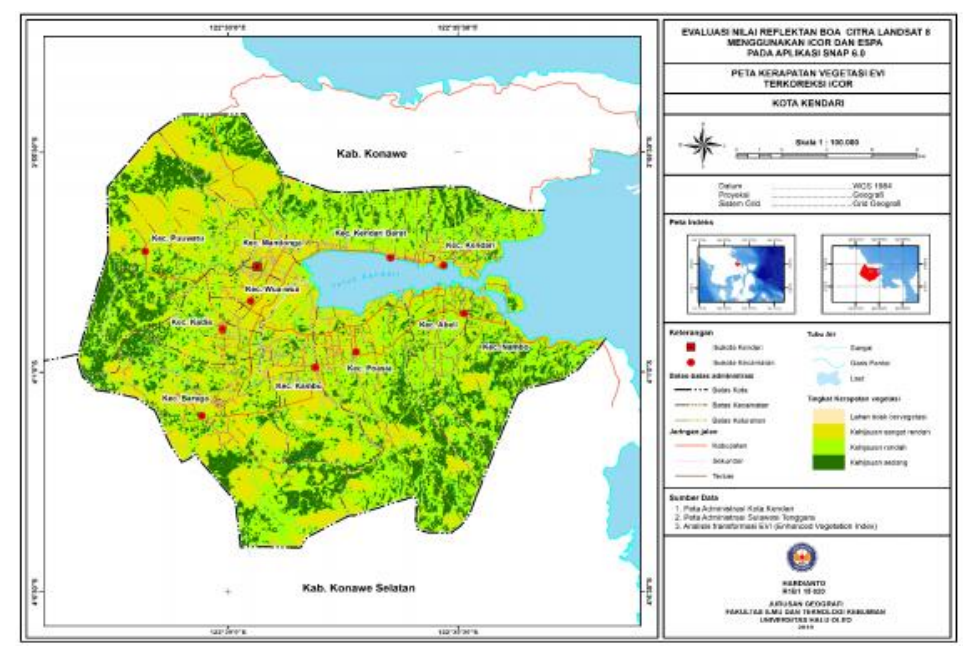

Gambar 6. Transformasi EVI Terkoreksi Atmosfer iCOR

Pada gambar 6 menunjukan tingkat kerapatan vegetasi transformasi EVI dengan empat rentang kelas, diataranya lahan tidak bervegetasi berwarna krim, kehijauan rendah berwarna kuning muda, kehijauan sedang berwarna hijau dan kehijauan tinggi berwarna hijau.

\section{Menerapkan hasil koreksi BoA iCOR pada indeks vegetasi \\ Normalized Difference Vegetation Indeks}

Hasil penerapan metode koreksi atmosfer iCOR pada transformasi NDVI menunjukan hasil dimana, pada hasil koreksi atmosfer iCOR rentan transfomasi NDVI dari -0,63 sampai dengan 1,42. Hasil terapan koreksi atmosfer iCOR yang diterapkan pada NDVI, menunjukan hasil nilai yang cukup baik dimana hasil transformasi NDVI yang di peroleh rentang nilai indeks vegetasinya mendekati rentang indeks vegetasi secara global yaitu -1 sampai dengan 1 . Adapun nilai tingkata kerapatan trasnformasi NDVI terkoreksi iCOR dapat dilihat pada Tabel 3

Tabel 3. Nilai kerapatan transformasi NDVI terkoreksi atmosfer iCOR

\begin{tabular}{lccc}
\hline \multirow{2}{*}{$\begin{array}{c}\text { Stasiun } \\
\text { pengamatan }\end{array}$} & \multicolumn{2}{c}{ Koordinat } & NDVI \\
\cline { 2 - 4 } & $\mathbf{X}$ & $\mathbf{Y}$ & $\begin{array}{c}\text { iCOR Surface } \\
\text { reflektance } \text { BoA }\end{array}$ \\
\hline sta_1 & 122.615523 & -3.989711 & 0.70 \\
\hline sta_2 & 122.605258 & -3.981292 & 0.81 \\
\hline
\end{tabular}

\begin{tabular}{|c|c|c|c|}
\hline \multirow{2}{*}{$\begin{array}{c}\text { Stasiun } \\
\text { pengamatan }\end{array}$} & \multicolumn{2}{|c|}{ Koordinat } & \multirow{2}{*}{$\begin{array}{c}\text { NDVI } \\
\text { iCOR Surface } \\
\text { reflektance BoA }\end{array}$} \\
\hline & $\mathbf{X}$ & $\mathbf{Y}$ & \\
\hline sta_3 & 122.590122 & -3.98427 & 0.73 \\
\hline sta_4 & 122.573095 & -3.988333 & 0.53 \\
\hline sta_5 & 122.553634 & -3.995379 & 0.76 \\
\hline sta_6 & 122.533643 & -3.981798 & 0.81 \\
\hline sta_7 & 122.529864 & -3.974468 & 0.81 \\
\hline sta_8 & 122.5323 & -3.966598 & 0.29 \\
\hline sta_9 & 122.548515 & -3.965793 & 0.44 \\
\hline sta_10 & 122.561757 & -3.964986 & 0.73 \\
\hline sta_11 & 122.585807 & -3.968255 & 0.73 \\
\hline sta_12 & 122.594724 & -3.969617 & 0.79 \\
\hline sta_13 & 122.603642 & -3.96935 & 0.86 \\
\hline sta_14 & 122.574999 & -3.963908 & 0.72 \\
\hline sta_15 & 122.513653 & -3.96903 & 0.42 \\
\hline sta_16 & 122.524736 & -3.963337 & 0.75 \\
\hline sta_17 & 122.500144 & -3.964137 & 0.61 \\
\hline sta_18 & 122.510941 & -3.985312 & 0.73 \\
\hline sta_19 & 122.523369 & -3.990205 & 0.80 \\
\hline sta_20 & 122.528229 & -3.998078 & 0.81 \\
\hline sta_21 & 122.541745 & -3.990487 & 0.79 \\
\hline sta_22 & 122.574436 & -4.008145 & 0.83 \\
\hline sta_23 & 122.544974 & -4.016543 & 0.65 \\
\hline sta_24 & 122.486344 & -3.993168 & 0.74 \\
\hline sta_25 & 122.473928 & -3.969006 & 0.55 \\
\hline sta_26 & 122.54091 & -4.035267 & 0.73 \\
\hline sta_27 & 122.512807 & -4.028466 & 0.40 \\
\hline sta_28 & 122.485792 & -4.011894 & 0.81 \\
\hline
\end{tabular}

April --- 59 
| Vol.5 | No.1| 2021

\begin{tabular}{lccc}
\hline \multirow{2}{*}{$\begin{array}{c}\text { Stasiun } \\
\text { pengamatan }\end{array}$} & \multicolumn{2}{c}{ Koordinat } & NDVI \\
\cline { 2 - 4 } & $\mathbf{X}$ & Y & $\begin{array}{c}\text { iCOR Surface } \\
\text { reflektance } \text { BoA }\end{array}$ \\
\hline sta_29 & 122.523121 & -3.951395 & 0.83 \\
\hline sta_30 & 122.561453 & -4.028493 & 0.52
\end{tabular}

Sumber : Analisis transformasi NDVI

\section{a. Soil Adjusted Vegetation Indeks}

Dari hasil penerapan metode koreksi atmosfer iCOR pada transformasi SAVI menunjukan hasil dimana, pada hasil koreksi atmosfer iCOR rentan transfomasi NDVI dari -0,14 sampai dengan 0,37. Dari hasil terapan koreksi atmosfer iCOR yang diterapkan pada SAVI, menunjukan hasil nilai yang kurang baik dimana hasil transformasi SAVI yang di peroleh rentang nilai indeks vegetasinya tidak mendekati rentang indeks vegetasi secara global yaitu -1 sampai dengan 1. Adapun nilai tingkata kerapatan trasnformasi SAVI terkoreksi iCOR dapat dilihat pada Tabel 4.

Tabel 4. Nilai kerapatan transformasi SAVI terkoreksi atmosfer iCOR

\begin{tabular}{|c|c|c|c|}
\hline \multirow{2}{*}{$\begin{array}{c}\text { Stasiun } \\
\text { pengamatan }\end{array}$} & \multicolumn{2}{|c|}{ Koordinat } & \multirow{2}{*}{$\begin{array}{c}\text { SAVI } \\
\text { iCOR Surface } \\
\text { reflektance BoA }\end{array}$} \\
\hline & $\mathbf{X}$ & $\mathbf{Y}$ & \\
\hline sta_1 & 122.615523 & -3.989711 & 0.20 \\
\hline sta_2 & 122.605258 & -3.981292 & 0.24 \\
\hline sta_3 & 122.590122 & -3.98427 & 0.21 \\
\hline sta_4 & 122.573095 & -3.988333 & 0.15 \\
\hline sta_5 & 122.553634 & -3.995379 & 0.24 \\
\hline sta_6 & 122.533643 & -3.981798 & 0.21 \\
\hline sta_7 & 122.529864 & -3.974468 & 0.21 \\
\hline sta_8 & 122.5323 & -3.966598 & 0.09 \\
\hline sta_9 & 122.548515 & -3.965793 & 0.13 \\
\hline sta_10 & 122.561757 & -3.964986 & 0.22 \\
\hline sta_11 & 122.585807 & -3.968255 & 0.22 \\
\hline sta_12 & 122.594724 & -3.969617 & 0.23 \\
\hline sta_13 & 122.603642 & -3.96935 & 0.27 \\
\hline sta_14 & 122.574999 & -3.963908 & 0.18 \\
\hline sta_15 & 122.513653 & -3.96903 & 0.13 \\
\hline sta_16 & 122.524736 & -3.963337 & 0.25 \\
\hline sta_17 & 122.500144 & -3.964137 & 0.20 \\
\hline sta_18 & 122.510941 & -3.985312 & 0.24 \\
\hline sta_19 & 122.523369 & -3.990205 & 0.26 \\
\hline sta_20 & 122.528229 & -3.998078 & 0.27 \\
\hline
\end{tabular}

\begin{tabular}{lccc}
\hline \multirow{2}{*}{$\begin{array}{c}\text { Stasiun } \\
\text { pengamatan }\end{array}$} & $\mathbf{X}$ & $\mathbf{Y}$ & \begin{tabular}{c} 
KAVI \\
\cline { 2 - 4 } reflektance BoA
\end{tabular} \\
\cline { 2 - 4 } sta_21 & 122.541745 & -3.990487 & 0.22 \\
\hline sta_22 & 122.574436 & -4.008145 & 0.25 \\
\hline sta_23 & 122.544974 & -4.016543 & 0.22 \\
\hline sta_24 & 122.486344 & -3.993168 & 0.23 \\
\hline sta_25 & 122.473928 & -3.969006 & 0.18 \\
\hline sta_26 & 122.54091 & -4.035267 & 0.23 \\
\hline sta_27 & 122.512807 & -4.028466 & 0.15 \\
\hline sta_28 & 122.485792 & -4.011894 & 0.27 \\
\hline sta_29 & 122.523121 & -3.951395 & 0.25 \\
\hline sta_30 & 122.561453 & -4.028493 & 0.18
\end{tabular}

Sumber : Analisis transformasi SAVI

\section{b. Enhanched Vegetation Index}

Dari hasil penerapan metode koreksi atmosfer iCOR pada transformasi EVI menunjukan hasil dimana, pada hasil koreksi atmosfer iCOR rentan transfomasi EVI dari -0,15 sampai dengan 0,35. Dari hasil terapan koreksi atmosfer iCOR yang diterapkan pada EVI, menunjukan hasil nilai yang kurang cukup baik dimana hasil transformasi EVI yang di peroleh rentang nilai indeks vegetasinya tidak mendekati rentang indeks vegetasi secara global yaitu -1 sampai dengan 1. Adapun nilai tingkata kerapatan trasnformasi EVI terkoreksi iCOR dapat dilihat pada Tabel 5.

Tabel 5. Nilai kerapatan transformasi EVI terkoreksi atmosfer iCOR

\begin{tabular}{|c|c|c|c|}
\hline \multirow{2}{*}{$\begin{array}{c}\text { Stasiun } \\
\text { pengamatan }\end{array}$} & \multicolumn{2}{|c|}{ Koordinat } & \multirow{2}{*}{$\begin{array}{c}\text { SAVI } \\
\begin{array}{c}\text { iCOR Surface } \\
\text { reflektance BoA }\end{array}\end{array}$} \\
\hline & $\mathbf{X}$ & $\mathbf{Y}$ & \\
\hline sta_1 & 122.615523 & -3.989711 & 0.18 \\
\hline sta_2 & 122.605258 & -3.981292 & 0.23 \\
\hline sta_3 & 122.590122 & -3.98427 & 0.20 \\
\hline sta_4 & 122.573095 & -3.988333 & 0.14 \\
\hline sta_5 & 122.553634 & -3.995379 & 0.23 \\
\hline sta_6 & 122.533643 & -3.981798 & 0.19 \\
\hline sta_7 & 122.529864 & -3.974468 & 0.19 \\
\hline sta_8 & 122.5323 & -3.966598 & 0.08 \\
\hline sta_9 & 122.548515 & -3.965793 & 0.13 \\
\hline sta_10 & 122.561757 & -3.964986 & 0.20 \\
\hline sta_11 & 122.585807 & -3.968255 & 0.21 \\
\hline sta_12 & 122.594724 & -3.969617 & 0.22 \\
\hline
\end{tabular}




\begin{tabular}{|c|c|c|c|}
\hline \multirow{2}{*}{$\begin{array}{c}\text { Stasiun } \\
\text { pengamatan }\end{array}$} & \multicolumn{2}{|c|}{ Koordinat } & \multirow{2}{*}{$\begin{array}{c}\text { SAVI } \\
\text { iCOR Surface } \\
\text { reflektance BoA }\end{array}$} \\
\hline & $\mathbf{X}$ & $\mathbf{Y}$ & \\
\hline sta_13 & 122.603642 & -3.96935 & 0.25 \\
\hline sta_14 & 122.574999 & -3.963908 & 0.17 \\
\hline sta_15 & 122.513653 & -3.96903 & 0.12 \\
\hline sta_16 & 122.524736 & -3.963337 & 0.23 \\
\hline sta_17 & 122.500144 & -3.964137 & 0.19 \\
\hline sta_18 & 122.510941 & -3.985312 & 0.22 \\
\hline sta_19 & 122.523369 & -3.990205 & 0.24 \\
\hline sta_20 & 122.528229 & -3.998078 & 0.26 \\
\hline sta_21 & 122.541745 & -3.990487 & 0.20 \\
\hline sta_22 & 122.574436 & -4.008145 & 0.24 \\
\hline sta_23 & 122.544974 & -4.016543 & 0.21 \\
\hline sta_24 & 122.486344 & -3.993168 & 0.21 \\
\hline sta_25 & 122.473928 & -3.969006 & 0.17 \\
\hline sta_26 & 122.54091 & -4.035267 & 0.22 \\
\hline sta_27 & 122.512807 & -4.028466 & 0.14 \\
\hline sta_28 & 122.485792 & -4.011894 & 0.26 \\
\hline sta_29 & 122.523121 & -3.951395 & 0.24 \\
\hline sta_30 & 122.561453 & -4.028493 & 0.16 \\
\hline
\end{tabular}

Sumber : Analisis transformasi EVI

\section{KESIMPULAN}

Berdasarkan tujuan dan hasil penelitian maka peneliti menyimpulkan sebagai berikut : Hasil terapan koreksi BoA iCOR pada indeks vegetasi NDVI memiliki nilai rentang kerapatannya $-0,63$ sampai dengan 1,42, pada transformasi SAVI rentang nilai kerapatannya $-0,14$ sampai 0,37 dan pada hasil transformasi EVI rentang nilai kerapatannya $-0,15$ sampai 0,35 .

\section{DAFTAR PUSTAKA}

Andana, Erie Kresna. 2015. Pengembangan Data Citra Satelit Landsat-8 Untuk Pemetaan Area Tanaman Hortikultura Dengan Berbagai Metode Algoritma Indeks Vegetasi (Studi Kasus: Kabupaten Malang Dan Sekitarnya). Prosiding Seminar Nasional Manajemen Teknologi XXII. P.1 -10

Arafah, Feni, Muhammad Taufik dan Lalu Muhammad Jaelani. 2018. Analisis Parameter Kualitas Air Laut Di Perairan Kabupaten Sumenep Untuk
Pembuatan Peta Sebaran Potensi Ikan Pelagis (Studi Kasus : Total Suspended Solid (Tss)). Prosiding Seminar Nasional Aplikasi Teknologi Prasarana Wilayah (Atpw), Surabaya. P. 21-30

Hernawati Rika, Agung Budi Harto dan Dewi Kania Sari. 2017. Pemetaan Pola Tanam Dan Kalender Tanam Padi Sawah Menggunakan Teknik Pengindraan Jauh. Jurnal Online Institut Teknologi Nasional. Vol. 1, No. 2. p. 91-111.

Himayah Shafira. Hartono. Dan Projo Danoedoro. 2017. Pemanfaatan Citra Landsat 8 Multitemporal dan Model Forest Canopy Density (FCD) untuk Analisis Perubahan Kerapatan Kanopi Hutan di Kawasan Fakultas Geografi Universitas Gadjah Mada Gunung Kelud, Jawa Timur. Majalah geografi Indonesia. Vol. 31, No. 1. p. 65-72

Ikkarnila, Djafar Mey dan Fitra Saleh. 2017. Analisis Spasial Kebutuhan Ruang Terbuka Hijau Dan Potensi Biomassa Di Kota Baubau. Jurnal Jagat. Vol 1. No 1. p. 51-62.

Kristianingsih, Lilik. Arwan Putra Wijaya dan Abdi Sukmono. 2016. Analisis Pengaruh Koreksi Atmosfer Terhadap Estimasi Kandungan Klorofil-A Menggunakan Citra Landsat 8. Jurnal Geodesi. Vol.5, No. 4. p. 56-64

Nurgiantoro, Wayan Mustika dan Abriansyah. 2019. Tinjauan Penginderaan Jauh Optik Untuk Pemantauan Total Suspended Solid Di Teluk Kendari. Prosiding Seminar Nasional Geografi II Pemanfaatan Big Data Dalam Pengembangan Keilmuan Geografi. P. 1126-1132.

Nurilmi, Mahmud Achmad dan Suhardi. 2017. Pendugaan Lengas Tanah Inceptisol Pada Tanaman Hortikultura Menggunakan Citra Landsat 8. Jurnal AgriTechno. Vol 10. No 2. p. 135-151. 
Peraturan Menteri Kehutanan Republik Indonesia Nomor : P.12/MenhutII/2012 Tentang Perubahan Kedua Atas Peraturan Menteri Kehutanan Nomor P.32/Menhut-II/2009 Tentang Tata Cara Penyusunan Rencana Teknik Rehabilitasi Hutan Dan Lahan Daerah Aliran Sungai (Rtk Rhl-Das). 31 Maret 2012. Tahun 2012 Nomor 296. Jakarta

Purwanto, Ajun. 2015. Pemanfaatan Citra Landsat 8 Untuk Identifikasi Normalized Difference Vegetation Index (Ndvi) Di Kecamatan Silat
Hilir Kabupaten Kapuas Hulu. Jurnal Edukasi. Vol. 13, No.1 p. 2736

Stefan Adriaensen, Sterckx Sindy, De Keukelaere Liesbeth, Ruben Van De Kerchove Els Knaeps. 2018. Atmospheric Correction Icor And Integration In Operational Workflows. P. 3524-3526

USGS. 2017. Landsat Surface ReflectanceDerived Spectral Indices. Amerika: Department of the Interior U.S. Geological Survey. 